\title{
Customers' Intention to Recommend Takeaway Food during COVID-19 Pandemic
}

\author{
DOI: 10.12776/QIP.V25I3.1621
}

\author{
Yulia Yeni, Vera Pujani, Laura Syahrul
}

Received: 2021-11-01 Accepted: 2021-11-23 Published: 2021-11-30

\begin{abstract}
Purpose: The aim of this study is to predict perceived risk and consumer willingness in recommending takeaway food from restaurant served in buffet style.

Methodology/Approach: This study used an online survey of 170 consumers who were selected based on purposive sampling method. The research questionnaire was adapted from previous research. The data were analysed using Structural Equation Modelling (SEM), with Smart PLS.

Findings: The research findings show that health risk and psychological risk have a positive effect on intention to recommend takeaway food. Meanwhile, quality risk and trust have no effect on intention to recommend takeaway food. In addition, psychological risk and quality risk have no effect on trust. This study also shows that trust does not function as a mediator of the relationship between health risk, psychological risk, quality risk, trust, and intention to recommend.
\end{abstract}

Research Limitation/Implication: This study only uses a self-report questionnaire by customers. For further research, to enrich the discussion, it is recommended to use interviews or FGD. In addition, this study only uses three risk variables. For the future, it is advisable to add other risk variables.

Originality/Value of paper: In other countries such as China, Korea and the United States, related research has been carried out, however for the context of RM Padang which is unique with all the menus served (Buffet) on the visiting customers' table has not been found in literature.

Category: Research paper

Keywords: health risk; psychological risk; quality risk; trust; intention to recommend 


\section{INTRODUCTION}

The Indonesian government has set up various efforts to break the chain of COVID-19 that has hit the world since March 2020, such as stay at home, work and study from home, Large-Scale Social Restrictions, Rapid Tests, SWAB Tests, Antigen Tests, and Vaccinations. In order to adapt with the new habits, The Decree of the Minister of Health No. HK.01.07/MENKES/382/2020 has been launched to respond to the pandemic disaster. A longitudinal study in the United States found that more than $50 \%$ of restaurant consumers did not want to dine in (Gursoy and Chi, 2020). Restaurants have to set up their activity to respond by adapting to new habits. Consumers feel uncomfortable eating and spend a longer time in restaurants.

In general, research conducted during the COVID-19 Pandemic confirms that restaurants are the worst affected sectors by social distancing regulations implemented by governments worldwide (Gössling, Scott and Hall, 2020). The business has adjusted its processes and strategies to keep up with changes in consumer behaviour. Nowadays, people must implement health protocols such as wearing masks, washing hands with soap and running water, maintaining distance, staying away from crowds and limiting mobilization and interaction. During the current crisis, consumers are generally more careful in their activities outside the house, especially in public places and facilities. Changing consumer behaviour is in line with the Indonesian government's appeal through the Decree of the Minister of Health No. HK.01.07/MENKES/382/2020 concerning Protocols for Public Health in Public Places and Facilities on June 19, 2020. According to this decree, public places and facilities include markets and the like; Malls/shops and the like; Hotels/inns/homestays/dormitory and the like, restaurants and the like, sports facilities and activities, modes of transportation, stations/terminals/ports/airports, tourist sites, beauty/hair care services and the like, creative economy services, religious services activities in houses of worship, and services for organizing events/meetings. In addition, Kurniawan (2020), in his article published in the online Economic Balance Sheet, explained Restaurant is one of the scary places for COVID-19 transmission.

In relation to previous explanation, the Indonesian Hotel and Restaurant Association made a "New Normal Guide for Hotels and Restaurants" for the members. The guide explains that the presentation of all types of condiments cannot be directly served at the table but must be served according to the requests of visiting consumers (Agmasari, 2020). Thus the presentation of buffet food (dishes) on dining table such as in the typical Padang Restaurants (or more well known as RM Padang) is not recommended. In order to survive in these difficult situation, therefore, the RM Padang owners need to rearrange marketing strategies in accordance with the conditions of the COVID-19 pandemic so that consumers continue to shop while paying attention to the health aspect. 
This research is motivated by the findings of previous study in the United States reported by Gursoy and Chi (2020) and the New Normal Guide for Hotels and Restaurants compiled by PHRI (Indonesian Hotel and Restaurant Association) aimed to develop marketing strategies at RM Padang through the application of Prospect theory. The theory developed by Kahneman and Tversky (1979) is widely used to observe consumer behaviour by considering uncertainty and risk in shopping decisions. Therefore, this theory is very suitable for the COVID-19 Pandemic conditions, especially during adaptation of new habits.

According to the research on consumer behaviour in restaurants in the United States, about $35 \%$ of restaurant consumers are willing to pay more for increased safety against possible health risks (Gursoy, Chi and Chi, 2020). To confirm this finding, it is deemed necessary to conduct a similar study in Indonesia. The problem to be investigated is related to consumer behaviour at RM Padang. So, the problem to be studied is: how are the effects of health risk, psychological risk, quality risk and trust toward intention to recommend takeaway food from RM Padang?

\section{LITERATURE REVIEW AND HYPOTHESES DEVELOPMENT}

This research focuses on the implementation of Prospect Theory developed by Kahneman and Tversky (1979). Trust is added as a determinant of intention to recommend and also as a mediating variable.

\subsection{Prospect Theory}

Many studies used Prospect Theory to predict consumer behaviour based on reallife choices (Al-Ansi, Olya and Han, 2019; Olya and Al-Ansi, 2018; Radic et al., 2021). This theory reveals that consumers make decisions based on the value of potential loss and gain outcomes and evaluate these losses and gains using specific heuristics (Olya and Al-Ansi, 2018). During Pandemic COVID-19 most consumers consider uncertain situation with relatively high health risk, so their final decision to buy or consume the product is based on the perceived advantage (Radic et al., 2021). Therefore, Prospect Theory is recommended and suitable to utilize in times of crisis with full of risk and uncertainty by using Health Risk, Psychological Risk, Quality Risk as the consumer consideration (Al-Ansi and Han, 2019; Day et al., 2020). Most previous studies have used this prospect theory for the hospitality industry. However, there is a limited number of studies focusing on takeaway food. There has been no published research using this theory to formulate marketing strategies for full service restaurants such as RM Padang. In general, previous studies have used this prospect theory for the hospitality industry. 


\subsection{Hypotheses Development}

Consumer behaviour theory explains that a person's desires and actions start from looking for goods or services needed, buying, using and deciding to continue using or discontinuing or recommending to others in the future. Such future behaviour is referred to as behavioural intention (Han and Hyun, 2017). It can be seen that intention to recommend is a part of behavioural intention (Jani and Han, 2011).

Risk is one of the factors that influence consumer decision making in choosing and buying a product. Several studies have found risk and trust have positive effects on purchase intention (Day et al., 2020; Hoque and Alam, 2018). This study confirmed the findings of Al-Ansi, Olya and Han (2019) which explained that health risk, psychological risk, quality risk, which are part of general risk, have a positive and significant impact on trust and intention to recommend halal food. Related to the findings of previous research, this study also examines the role of trust as a mediating variable in the relationship between risk and intention to recommend. Therefore, this study proposes ten hypotheses as follows:

H1: Health risk has a positive effect on the intention to recommend takeaway food from RM Padang.

H2: Psychological risk has a positive effect on the intention to recommend takeaway food from RM Padang.

H3: Quality risk has a positive effect on the intention to recommend takeaway food from RM Padang.

H4: Trust has a positive effect on the intention to recommend takeaway food from RM Padang.

H5: Health risk has a positive effect on the intention to recommend takeaway food from RM Padang.

H6: Psychological risk has a positive effect on the intention to recommend takeaway food from RM Padang.

H7: Quality risk has a positive effect on the intention to recommend takeaway food from RM Padang.

H8: Health risk has a positive effect on the intention to recommend takeaway food from RM Padang through trust.

H9: Psychological risk has a positive effect on the intention to recommend takeaway food from RM Padang through trust.

H10: Quality risk has a positive effect on the intention to recommend takeaway food from RM Padang through trust. 


\section{METHODOLOGY}

Data was collected online through an administered questionnaire by consumers with the criteria of having made a purchase takeaway food from RM Padang. Respondents were selected with a non-probability sampling approach, specifically purposive sampling. Based on the $G$ power sample size calculator (Kang, 2021), with statistical power: 0.95 and $\alpha$ error 0.05 , the calculation suggests the minimum sample that must be collected to answer research questions is 129 . This is also consider 4 predictors from 5 constructs consisting of health risk, psychological risk, and quality risk, as an independent variable, trust has a dual role as the independent variable and mediating variable and the intention to recommend.

To obtain consumer perceptions on the 5 constructs, a research instrument was developed using a 7-point Likert scale from 1 (strongly disagree) to 7 (strongly disagree). This instrument was adopted and adapted from previous research, such as Indicators of Health Risk, Psychological Risk and Quality Risk (Al-Ansi and Han, 2019; Al-Ansi, Olya and Han, 2019; Hwang and Choe, 2020), Trust and Intention to Recommend (Al-Ansi, Olya and Han, 2019).

The distribution of Google Forms through WhatsApp groups managed to collect 170 data that were suitable for further processing. The following Table 1 shows the characteristics of the respondents.

Table 1 - The Characteristics of the Respondents

\begin{tabular}{|l|l|c|c|}
\hline \multicolumn{2}{|l|}{ Characteristics } & Frequency & Percent \\
\hline \multirow{3}{*}{ Sex } & Male & 58 & $34.10 \%$ \\
\cline { 2 - 4 } & Female & 112 & $65.90 \%$ \\
\hline \multirow{5}{*}{ Age } & $<26$ years & 50 & $29.40 \%$ \\
\cline { 2 - 4 } & $26-40$ years & 81 & $47.60 \%$ \\
\cline { 2 - 4 } & $41-55$ years & 30 & $17.60 \%$ \\
\cline { 2 - 4 } & $56-70$ years & 9 & $5.30 \%$ \\
\cline { 2 - 4 } & Below high school & 4 & $2.40 \%$ \\
\cline { 2 - 4 } & High school & 10 & $5.90 \%$ \\
\cline { 2 - 4 } & Junior college & 89 & $5.20 \%$ \\
\cline { 2 - 4 } & Undergraduate & 44 & $25.90 \%$ \\
\cline { 2 - 4 } & Master & 9 & $5.30 \%$ \\
\cline { 2 - 4 } & Doctor & & \\
\hline
\end{tabular}




\begin{tabular}{|l|l|c|c|}
\hline \multicolumn{2}{|l|}{ Characteristics } & Frequency & Percent \\
\hline \multirow{5}{*}{ Occupation } & Student & 33 & $19.40 \%$ \\
\cline { 2 - 4 } & Private company employee & 41 & $24.10 \%$ \\
\cline { 2 - 4 } & Government employee & 40 & $23.50 \%$ \\
\cline { 2 - 4 } & Entrepreneur & 23 & $13.50 \%$ \\
\cline { 2 - 4 } & Housewife & 8 & $4.70 \%$ \\
\cline { 2 - 4 } & Retired & 1 & $0.60 \%$ \\
\cline { 2 - 4 } & Others & 24 & $14.10 \%$ \\
\hline Total & & & $100 \%$ \\
\hline
\end{tabular}

\section{DATA ANALYSIS AND DISCUSSION}

The data, collected from respondents who meet the specified criteria, is processed using structural equation modelling (SEM) using SmartPLS 3.2.9 software. There are 2 stages of testing that must be carried out on PLS, namely testing the outer model and testing the inner model. First, outer model test is the assessment of the validity and reliability of the measurement. A measurement model testing using a research instrument is said to be reliable if the value of Cronbach alpha or composite reliability is 0.7 . Second, Structural model or inner model test the hypothesis by looking at the results of the t-statistics (table between constructs). This table consists of the original sample estimate value, the mean of subsamples and the standard deviation. Provisions on the results of hypotheses testing for 1 tail if the t-statistic value is higher than 1.645 (t-table) then the hypothesis statement is supported. However, if the t-statistic value is lower than 1.645 then the hypothesis statement is not supported (Sekaran and Bougie, 2016).

Before the data was analysed with SEM, then a descriptive analysis and normality test were carried out. Table 2 below shows the results of the analysis.

Table 2 - Descriptive Statistics and Normality Assessment

\begin{tabular}{|l|c|c|c|c|c|c|c|}
\hline Construct & Indicator & Min & Max & Mean & $\begin{array}{c}\text { Standard } \\
\text { Deviation }\end{array}$ & $\begin{array}{c}\text { Excess } \\
\text { Kurtosis }\end{array}$ & Skewness \\
\hline \multirow{3}{*}{ HR } & HR1 & 2.000 & 7.000 & 6.100 & 1.083 & 1.960 & -1.407 \\
\cline { 2 - 8 } & HR2 & 1.000 & 7.000 & 6.106 & 1.143 & 2.618 & -1.545 \\
\cline { 2 - 8 } & HR3 & 1.000 & 7.000 & 5.735 & 1.374 & 0.894 & -1.159 \\
\cline { 2 - 8 } & HR4 & 1.000 & 7.000 & 6.035 & 1.132 & 2.353 & -1.396 \\
\hline PR & PR1 & 1.000 & 7.000 & 5.782 & 1.200 & 1.252 & -1.055 \\
\cline { 2 - 8 } & PR2 & 1.000 & 7.000 & 5.718 & 1.204 & 0.841 & -0.909 \\
\cline { 2 - 8 } & PR3 & 1.000 & 7.000 & 5.665 & 1.297 & 1.143 & -1.119 \\
\hline
\end{tabular}

ISSN 1335-1745 (print) ISSN 1338-984X (online) 


\begin{tabular}{|l|c|c|c|c|c|c|c|}
\hline Construct & Indicator & Min & Max & Mean & $\begin{array}{c}\text { Standard } \\
\text { Deviation }\end{array}$ & $\begin{array}{c}\text { Excess } \\
\text { Kurtosis }\end{array}$ & Skewness \\
\hline \multirow{3}{*}{ QR } & QR1 & 1.000 & 7.000 & 4.312 & 1.527 & -0.410 & -0.188 \\
\cline { 2 - 8 } & QR2 & 3.000 & 7.000 & 6.088 & 0.893 & 0.730 & -0.924 \\
\cline { 2 - 8 } & QR3 & 2.000 & 7.000 & 5.494 & 1.261 & -0.012 & -0.696 \\
\cline { 2 - 8 } & QR4 & 1.000 & 7.000 & 5.541 & 1.307 & 0.769 & -0.953 \\
\hline \multirow{4}{*}{ TR } & TR1 & 2.000 & 7.000 & 5.982 & 0.942 & 0.987 & -0.901 \\
\cline { 2 - 8 } & TR2 & 2.000 & 7.000 & 5.794 & 1.011 & 0.193 & -0.644 \\
\cline { 2 - 8 } & TR3 & 2.000 & 7.000 & 5.718 & 0.959 & 0.731 & -0.697 \\
\hline \multirow{3}{*}{ IN } & IN1 & 1.000 & 7.000 & 5.882 & 1.192 & 1.912 & -1.220 \\
\cline { 2 - 8 } & IN2 & 1.000 & 7.000 & 5.988 & 1.117 & 3.642 & -1.588 \\
\cline { 2 - 8 } & IN3 & 1.000 & 7.000 & 5.876 & 1.247 & 1.895 & -1.306 \\
\hline
\end{tabular}

Based on Table 2, the data is normally distributed because the skewness of all indicators is not greater than 2 and less than -2 . The normality of this data can also be seen from the kurtosis of all indicators which are between -7 and +7 . Thus, further analysis can be carried out.

\subsection{Measurement Model Assessment}

The assessments commonly carried out on the measurement model (outer model) with reflective constructs used in this research are convergent validity and discriminant validity. The results of the calculation of the outer model can be seen as follow.

Convergent Validity testing uses the following indicators: Outer Loading, Average Variance Extracted (AVE), and Internal Consistency Reliability. Based on the rule of thumb, Outer Loading all indicators must be statistically significant as indicated by a value $>0.708$. Table 3 indicates that the indicators of Quality Risk 2 (QR2) has outer loading value of $0.503<0.708$. Therefore, QR2 is deleted or not included in the next analysis. 
Table 3 - Outer Loading

\begin{tabular}{|c|c|c|c|}
\hline Construct & $\begin{array}{l}\text { Indicators } \\
\text { Code }\end{array}$ & Indicators Description & $\begin{array}{l}\text { Outer } \\
\text { Loading }\end{array}$ \\
\hline \multirow[t]{4}{*}{$\begin{array}{l}\text { Health Risk } \\
\text { (HR) }\end{array}$} & HR1 & $\begin{array}{l}\text { I worry about the implementation of health protocols in } \\
\text { restaurants if consuming food dine in. }\end{array}$ & 0.912 \\
\hline & HR2 & I worry about COVID-19 if I eat in a crowd & 0.926 \\
\hline & HR3 & $\begin{array}{l}\text { I worry about the quality of food that doesn't meet health } \\
\text { standards }\end{array}$ & 0.726 \\
\hline & HR4 & $\begin{array}{l}\text { During this COVID-19 pandemic, I'm worry about } \\
\text { consuming unhealthy food, if I eat in crowded places }\end{array}$ & 0.834 \\
\hline \multirow[t]{3}{*}{$\begin{array}{l}\text { Psychological } \\
\text { Risk (PR) }\end{array}$} & PR1 & $\begin{array}{l}\text { I feel anxious during this COVID-19 pandemic if I eat at a } \\
\text { restaurant }\end{array}$ & 0.948 \\
\hline & PR2 & $\begin{array}{l}\text { During this COVID-19 pandemic, I am not } \\
\text { psychologically comfortable eating at restaurants }\end{array}$ & 0.962 \\
\hline & PR3 & $\begin{array}{l}\text { During this COVID-19 Pandemic, based on my } \\
\text { experience, eating in a restaurant makes me unnecessarily } \\
\text { tensed. }\end{array}$ & 0.947 \\
\hline \multirow[t]{4}{*}{$\begin{array}{l}\text { Quality Risk } \\
\text { (QR) }\end{array}$} & QR1 & $\begin{array}{l}\text { I am concerned about the integrity of the restaurant } \\
\text { owners and employees regarding the quality of the food } \\
\text { offered }\end{array}$ & 0.710 \\
\hline & QR2 & $\begin{array}{l}\text { I care about the suitability of the quality of the food } \\
\text { ordered with what I expect. }\end{array}$ & 0.503 \\
\hline & QR3 & $\begin{array}{l}\text { I worry about the quality of the product that doesn't } \\
\text { match with the information in the ad. }\end{array}$ & 0.728 \\
\hline & QR4 & $\begin{array}{l}\text { I worry about the availability of food that meets health } \\
\text { standards during the COVID-19 pandemic }\end{array}$ & 0.842 \\
\hline \multirow[t]{3}{*}{ Trust (TR) } & TR1 & RM Padang provides trustworthy food & 0.935 \\
\hline & TR2 & RM Padang guarantees the quality of the food offered & 0.957 \\
\hline & TR3 & $\begin{array}{l}\text { I believe in the accuracy of the information that RM } \\
\text { Padang provides to consumers }\end{array}$ & 0.887 \\
\hline \multirow{3}{*}{$\begin{array}{l}\text { Intention to } \\
\text { Recommend } \\
\text { (IN) }\end{array}$} & IN1 & $\begin{array}{l}\text { I would recommend purchasing takeaway food from RM } \\
\text { Padang }\end{array}$ & 0.912 \\
\hline & IN2 & $\begin{array}{l}\text { I will say positive things about buying takeaway food } \\
\text { from RM Padang }\end{array}$ & 0.829 \\
\hline & IN3 & $\begin{array}{l}\text { I will encourage friends and relatives to buy takeaway } \\
\text { food from RM Padang }\end{array}$ & 0.908 \\
\hline
\end{tabular}

After QR 2 is deleted, the Outer Model analysis is carried out again by modifying the Model. The results of the analysis show that the remaining 16 indicators of the 17 indicators in the initial model have an outer loading of 0.705 to 0.962 . It is exhibited in Figure 1. 


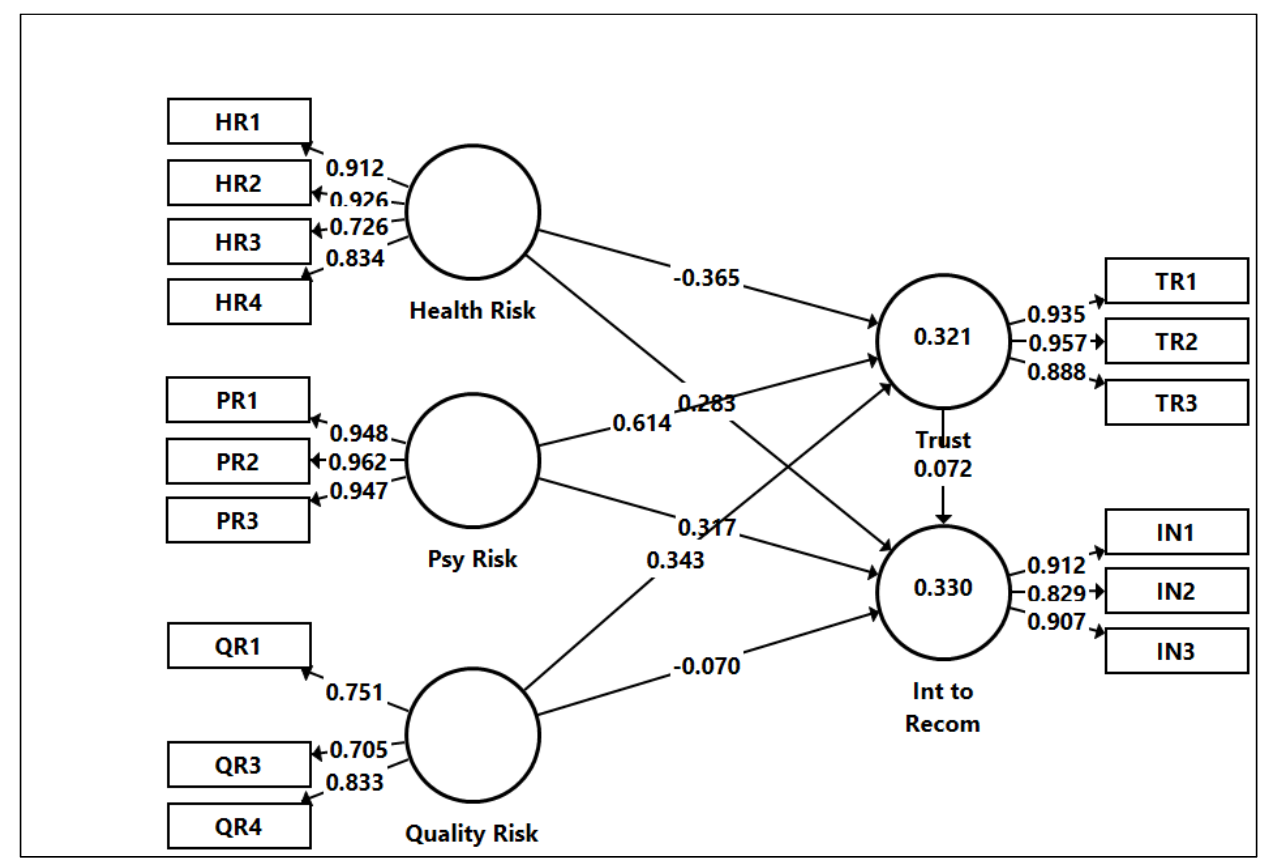

Figure 1 - Modified Model

Furthermore, the validity test is carried out by assessing the Average Variance Extracted (AVE). This AVE indicates how much variation in some items is explained by the latent variable. This AVE value is between 0 and 1 . According to Bagozzi and Yi (1988) and Fornell and Larcker (1981), the recommended AVE value is $>0.5$. Then table 4 represents the reliability test was carried out using Cronbach alpha and composite reliability.

Table 4 - Construct Reliability and AVE

\begin{tabular}{|l|c|c|c|c|}
\hline & Cronbach Alpha & rho_A & Composite Reliability & AVE \\
\hline HR & 0.877 & 0.928 & 0.914 & 0.728 \\
\hline IN & 0.866 & 0.930 & 0.914 & 0.781 \\
\hline PR & 0.949 & 0.949 & 0.967 & 0.907 \\
\hline QR & 0.657 & 0.672 & 0.808 & 0.585 \\
\hline TR & 0.918 & 0.921 & 0.948 & 0.859 \\
\hline
\end{tabular}

Table 4 shows that all constructs are reliable, as seen in the Cronbach Alpha value of 0.657 to 0.949 . Although generally accepted Cronbach Alpha is 0.7 but 0.657 of Quality Risk is acceptable in exploratory research for Takeaway food at RM Padang (Nunnally and Bernstein, 1994). The reliability of the variable construct used in this study is also indicated by the composite reliability value $>0.7$ with a range from 0.808 to 0.967 . 
Discriminant validity assessment aimed to see the correlation between constructs and other constructs. If the square root of the average AVE value of each construct (indicated by a number on the diagonal higher than the correlation value between constructs in the model), it can be said that the construct has a good valid level. The value of discriminant validity can be seen in Table 5 .

Table 5 - Discriminant Validity

\begin{tabular}{|l|c|c|c|c|c|}
\hline & HR & IN & PR & QR & TR \\
\hline HR & $\mathbf{0 . 8 5 3}$ & & & & \\
\hline IN & 0.528 & $\mathbf{0 . 8 8 4}$ & & & \\
\hline PR & 0.800 & 0.551 & $\mathbf{0 . 9 5 2}$ & & \\
\hline QR & 0.386 & 0.181 & 0.353 & $\mathbf{0 . 7 6 5}$ & \\
\hline TR & 0.258 & 0.256 & 0.443 & 0.419 & $\mathbf{0 . 9 2 7}$ \\
\hline
\end{tabular}

\subsection{Structural Model Assessment}

This study applies the PLS-SEM algorithm to estimate the structural model. This test begins by looking at the R-square value which is a goodness of fit test. The dependent variable R-square can be used to see the effect of the independent variable on the dependent variable. Assessment with PLS begins by looking at the R-square value for each dependent variable. Changes in the value of R-square can be used to see the effect of the independent variable on the dependent variable, whether it has a substantive effect. Analysis found R-square value is 0.33 for the intention to recommend and 0.321 for the Trust. Based on the index for predictive relevance of the recommended structural model higher than 0.10, the predictive ability of individual paths and structural models in this study has been satisfactory.

To test the hypothesis, it can be done by bootstrapping and looking at the probability value and t-statistics. The hypothesis will be accepted if the t-statistic $>$ t-table (1.645) for the two tails test. Table 6 shows assessment of the effect between the independent variable and the dependent variable concluded as follows:

- Health risk has a positive and significant effect on intent to recommend because the t-value of 2.139 is greater than 1.645. The Path Coefficient value of 0.257 indicates the direction of the positive effect.

- Psychological risk has a positive and significant effect on intention to recommend because the $\mathrm{t}$-values are 2.942>1.645. The Path Coefficient value of 0.361 indicates the direction of the positive effect.

- Quality risk has a negative and insignificant effect on intention to recommend because the $\mathrm{t}$-values are $0.534<$ from 1.645. The Path Coefficient value of -0.041 indicates the direction of the negative effect 
- Trust has a positive and insignificant effect on intention to recommend because the $\mathrm{t}$-values are $1.256<1.645$. The Path Coefficient value of 0.072 indicates the direction of the positive effect.

- Health risk has a positive and significant effect on trust because the tvalue of 3.902 is greater than 1.645. The Path Coefficient value of -0.365 indicates the direction of the negative effect.

- Psychological risk has a positive and significant effect on intention to recommend because the t-values are 6.410>1.645. The Path Coefficient value of 0.614 indicates the direction of the positive effect.

- Quality risk has a negative and insignificant effect on intention to recommend because the t-values are 5.164>1.645. The Path Coefficient value of 0.343 indicates the direction of the positive effect.

- Health risk has a negative and insignificant effect on intent to recommend mediated by trust because the t-value of 1.233 is less than 1.645. The Path Coefficient value of -0.026 indicates the direction of negative effect

- Psychological risk has a positive and insignificant effect on intention to recommend mediated by Trust because the t-values are $1.248<1.645$. The Path Coefficient value of 0.044 indicates the direction of the positive effect.

- Quality risk has a positive and insignificant effect on intention to recommend because the t-values are $1.168<1.645$. The Path Coefficient value of 0.025 indicates the direction of the positive effect.

Table 6 - Hypotheses Test

\begin{tabular}{|c|c|c|c|c|c|c|}
\hline Hypotheses & Path & Path Coefficient & Std Beta & Std Error & t-value & Decision \\
\hline \multicolumn{7}{|l|}{ Direct effect } \\
\hline H1 & $\mathrm{HR} \rightarrow \mathrm{IN}$ & 0.257 & 0.268 & 0.120 & 2.139 & Supported \\
\hline $\mathrm{H} 2$ & $\mathrm{PR} \rightarrow \mathrm{IN}$ & 0.361 & 0.352 & 0.123 & 2.942 & Supported \\
\hline H3 & $\mathrm{QR} \rightarrow \mathrm{IN}$ & -0.046 & -0.041 & 0.086 & 0.534 & Not Supported \\
\hline $\mathrm{H} 4$ & $\mathrm{TR} \rightarrow \mathrm{IN}$ & 0.072 & 0.071 & 0.057 & 1.250 & Not Supported \\
\hline H5 & $\mathrm{HR} \rightarrow \mathrm{TR}$ & -0.365 & -0.355 & 0.094 & 3.902 & Supported \\
\hline H6 & $\mathrm{PR} \rightarrow \mathrm{TR}$ & 0.614 & 0.602 & 0.096 & 6.410 & Supported \\
\hline $\mathrm{H} 7$ & $\mathrm{QR} \rightarrow \mathrm{TR}$ & 0.343 & 0.348 & 0.066 & 5.164 & Supported \\
\hline \multicolumn{7}{|c|}{ Indirect Effect } \\
\hline H8 & $\mathrm{HR} \rightarrow \mathrm{TR} \rightarrow \mathrm{IN}$ & -0.026 & -0.025 & 0.021 & 1.233 & Not Supported \\
\hline H9 & $\mathrm{PR} \rightarrow \mathrm{TR} \rightarrow \mathrm{IN}$ & 0.044 & 0.042 & 0.035 & 1.248 & Not Supported \\
\hline H10 & $\mathrm{QR} \rightarrow \mathrm{TR} \rightarrow \mathrm{IN}$ & 0.025 & 0.025 & 0.021 & 1.168 & Not Supported \\
\hline
\end{tabular}




\subsection{Discussion}

Assessment of $\mathrm{H} 1$ and $\mathrm{H} 2$ indicates that health and psychological risk has a positive and significant effect on the intention to recommend take away food from RM Padang. With the t-values of 2.139 and 2.942>1.645, hence $\mathrm{H} 1$ and $\mathrm{H} 2$ are supported. Path Coefficient of 0.257 and 0.361 indicate the direction of effect is positive. It means there are association customer perception about health and psychological risk with intention to recommend take away food during COVID19. In other words, if the health and psychological risk perception of customers increases, their intention to recommend takeaway food is also growing. Results of this study are in line with prior research which states that the perceived health and psychological risk affects customers' intention to recommend halal food (Olya and Al-Ansi, 2018). This finding also support similar study that suggests risk affects customer attitudes and behaviour (DeFranco and Morosan, 2017).

The result of this study also confirms the study of Olya and Al-Ansi (2018) found quality risk does not affect the intention to recommend halal food. Testing of $\mathrm{H} 3$ shows the quality of the food from the RM Padang restaurant will decrease if it is not consumed directly at the restaurant, so customers will have less intention to recommend buying takeaway food.

Based on the results of hypothesis testing, it is known that perceived risk, specifically psychological risk and quality risk, have a positive and significant effect on consumer trust in RM Padang. This is indicated by the psychological risk t-statistic value of 6.410 and quality risk of 5.164 which is greater than the ttable or 1.645. The results of this study are in line with research which states that risk has an important role to create trust and customer satisfaction (Olya and Altinay, 2016). In General, loyal customers will communicate positive recommendation. This result also supports prior relevant research which states that general risk has a significant and positive impact on trust of halal food (AlAnsi, Olya and Han, 2019). However, previous study of Hoque and Alam (2018) in Bangladesh found that perceived risk has a significant and negative effect on trust in liquid milk. The suggestion of that study is relevant with the finding about health risk has a significant negative effect on trust. It means increasing of perceived health risk (on pandemic situation for example) will erode trust on food of RM Padang.

Hypothesis testing of $\mathrm{H} 4$ conducted reveals that trust has a positive and significant effect on the customers' intention to recommend RM Padang. Since the t-statistic value of $1.250<1.645$, it is concluded that refusing or not supported which means that trust does not affect the intention to recommend takeaway Padang cuisine at RM Padang during COVID-19. The results of this study are not consistent with previous studies (Al-Ansi, Olya and Han, 2019; Shin et al., 2017). Differences in research findings between this research with previous research because of the different objects being studied and the different situations. 
The indirect effect of the health, psychological and quality risk on the intention to recommend mediated by trust is not significant, since the t-statistic value of the three risk variables $<\mathrm{t}$-table 1.645 . Therefore, the results of this research is not confirm the finding of previous research by Ling et al. (2011), Hong and Cha, (2013), Leeraphong and Mardjo (2013), and Artigas et al. (2017).

\section{CONCLUSION}

Based on the questionnaire distributed to the consumers of RM Padang and data analysed by using PLS SEM, it can be concluded that among the formulated hypotheses, 5 hypotheses are supported and another 5 hypotheses are not supported. The accepted hypothesis proves that risk has a significant positive effect on trust and intention to recommend. Health risk has a positive and significant effect on intention to recommend. Similarly, Psychological risk also has a positive and significant effect on intention to recommend. The research findings for these two risks indicate that the higher the consumers' concern about the risk of eating food served at RM Padang, both from their perception of health risks and from the psychological risk, the higher the consumers' intention to recommend buying takeaway food. Due to the uniqueness of the food and its presentation, it is understandable that quality risk has a negative effect on purchase intent. This shows that the higher the consumer's anxiety about the quality of takeaway food, the lower the consumer's intention to recommend it. With the same description, it can be explained that trust has also a positive effect on intention to recommend.

In general, respondents of this study are consumers who have visited and bought the food of RM Padang. Therefore, they already have an emotional bond with RM Padang in other words they believe that RM Padang really cares about the implementation of health protocols.

Based on the discussion above, it appears that there is diversity of research results related to the effects of 5 variables, namely health risk, psychological risk, quality risk, trust, and intention to recommend. Therefore, the findings of this study cannot be generalized. Future research is needed to confirm the results of this study by using qualitative research.

\section{ACKNOWLEDGEMENTS}

This research was funded by Faculty of Economics Universitas Andalas Padang, Indonesia through Research Grant Number: II/27/UN.16.5.D/SKMUnggulan/2021. 


\section{REFERENCES}

Agmasari, S., 2020. Panduan Makan di Restoran pada Era New Normal. Kompas, [online] 17 June 2020. Available at: <https://www.kompas.com/food/read/2020/06/17/070300275/panduan-makan-direstoran-pada-era-new-normal> [Accessed 24 October 2021].

Al-Ansi, A. and Han, H., 2019. Role of halal-friendly destination performances, value, satisfaction, and trust in generating destination image and loyalty. Journal of Destination Marketing and Management, [e-journal] 13, pp.51-60. DOI: 10.1016/j.jdmm.2019.05.007.

Al-Ansi, A., Olya, H.G.T. and Han, H., 2019. Effect of general risk on trust, satisfaction, and recommendation intention for halal food. International Journal of Hospitality Management, [e-journal] 83, pp.210-219. DOI: 10.1016/j.ijhm.2018.10.017.

Artigas, E.M., Yrigoyen, C.C., Moraga, E.T and Villalón, C.B., 2017. Determinants of trust towards tourist destinations. Journal Destination Marketing Management, [e-journal] 6(4), pp.327-334. DOI: 10.1016/j.jdmm.2017.03.003.

Bagozzi, R. and Yi, Y., 1988, On the Evaluation of Structural Equation Models. Journal of the Academy of Marketing Sciences, 16(1), pp.74-94.

Day, S., Godsell, J., Masi, D. and Zhang, W., 2020. Predicting consumer adoption of branded subscription services: A prospect theory perspective. Business Strategy and the Environment, [e-journal] 29(3), pp.1310-1330. DOI: 10.1002/bse.2435.

DeFranco, A. and Morosan, C., 2017. Coping with the risk of internet connectivity in hotels: Perspectives from American consumers traveling internationally. Tourism Management, [e-journal] 61, pp.380-393. DOI: 10.1016/j.tourman.2017.02.022.

Fornell, C. and Larcker, D.F., 1981. Evaluating Structural Equation Models with Unobservable Variables and Measurement Error. Journal of Marketing Research, 18(Feb), pp.39-50.

Gössling, S., Scott, D. and Hall, C.M., 2020. Pandemics, tourism and global change: a rapid assessment of COVID-19. Journal of Sustainable Tourism, [ejournal] 29(1), pp.1-20. DOI: 10.1080/09669582.2020.1758708.

Gursoy, D. and Chi, C.G., 2020. Effects of COVID-19 pandemic on hospitality industry: review of the current situations and a research agenda. Journal of Hospitality Marketing and Management. [e-journal] 29(5), pp.527-529. DOI: 10.1080/19368623.2020.1788231.

Gursoy, D., Chi, C.G. and Chi, O.H., 2020. Restaurant and Hotel Industry Restaurant and hotel customers' sentiment analysis Would they come back? If they would, when?. Pullman, WA: School of Hospitality Business Management, Carson College of Business at Washington State University. 
Han, H. and Hyun, S.S., 2017. Impact of hotel-restaurant image and quality of physical-environment, service, and food on satisfaction and intention. International Journal of Hospitality Management, [e-journal] 63, pp.82-92. DOI: 10.1016/j.ijhm.2017.03.006.

Hong, I.B. and Cha, H.S., 2013. The mediating role of consumer trust in an online merchant in predicting purchase intention. International Journal of Information Management, [e-journal] 33(6), pp.927-939. DOI: 10.1016/j.ijinfomgt.2013.08.007.

Hoque, M.Z. and Alam, M.N., 2018. What determines the purchase intention of liquid milk during a food security crisis? The role of perceived trust, knowledge, and risk. Sustainabilit, [e-journal] 10(10), pp.1-22. DOI: 10.3390/su10103722.

Olya, H.G.T. and Al-Ansi, A., 2018. Risk assessment of halal products and services: Implication for tourism industry. Tourism Management, [e-journal] 65, pp.279-291. DOI: 10.1016/j.tourman.2017.10.015.

Olya, H.G.T. and Altinay, L.,2016. Asymmetric modeling of intention to purchase tourism weather insurance and loyalty. Journal of Business Research, [e-journal] 69(8), pp.2791-2800. DOI: 10.1016/j.jbusres.2015.11.015.

Hwang, J. and Choe, J.Y., 2020. How to enhance the image of edible insect restaurants: Focusing on perceived risk theory. International Journal of Hospitality Management, [e-journal] 87, pp.102-464. DOI: 10.1016/j.ijhm.2020.102464.

Jani, D. and Han, H., 2011. Investigating the key factors affecting behavioral intentions: Evidence from a full-service restaurant setting. International Journal of Contemporary Hospitality Management, [e-journal] 23(7), pp.1000-1018. DOI: 10.1108/09596111111167579.

Kahneman, D. and Tversky, A., 1979. Prospect Theory: An Analysis of Decision under Risk. Econometrica, 47(2), pp.263-292.

Kang, H., 2021. Sample size determination and power analysis using the G*Power software. Journal of Educational Evaluation for Health Professions, [e-journal] 18(17), pp.1-12. DOI: 10.3352/JEEHP.2021.18.17.

Kurniawan, I., 2020. Protokol Kesehatan dan Cara Mencegah Corona di Restoran. Neraca.co.id, [online] 19 September 2020. Available at: <https://www.neraca.co.id/article/136445/protokol-kesehatan-dan-caramencegah-corona-di-restoran> [Accessed 24 October 2021].

Leeraphong, A and Mardjo, A., 2013. Trust and risk in purchase intention through online social network: A focus group study of facebook in Thailand. Journal of Economics, Business and Management, 1(4), pp.314-318.

Ling, K.C., Dazmin, D., Tan, H.P. and Kay, H.K., 2011. Perceived risk, perceived technology, online trust for the online purchase intention in Malaysia. International Journal of Business and Management, [e-journal] 6(6), pp.167-182. DOI: $10.5539 / \mathrm{ijbm} . \mathrm{v} 6 \mathrm{n} 6 \mathrm{p} 167$. 
Nunnally, J.C. and Bernstein, I.H., 1994. Psychometric Theory. 3rd Edition. New York: McGraw Hill.

Radic, A., Lück, M., Al-Ansi, A., Chua, B.-L., Seeler, S., Raposo, A., Kim, J.J. and Han, H., 2021. To dine, or not to dine on a cruise ship in the time of the covid-19 pandemic: The tripartite approach towards an understanding of behavioral intentions among female passengers. Sustainability, [e-journal] 13(5), pp.1-18. DOI: $10.3390 / \mathrm{su} 13052516$.

Sekaran, U. and Bougie, R., 2016. Research Methods For Business: A Skill Building Approach. New Jersey: Wiley.

Shin, Y., Shin, Y., Thai, V.V., Thai, V.V., Grewal, D., Grewal, D. and Kim, Y., 2017. Do corporate sustainable management activities improve customer satisfaction, word of mouth intention and repurchase intention? Empirical evidence from the shipping industry. International Journal of Logistics Management, [e-journal] 28(2), pp.555-570. DOI: 10.1108/IJLM-11-2015-0220.

\section{ABOUT AUTHORS}

Yulia Yeni ${ }^{0000-0002-5242-4572}$ (Y.Y.) - Assoc. Prof., Faculty of Economics, Universitas Andalas, Indonesia, e-mail: yuliahendriyeni@eb.unand.ac.id.

Vera Pujani ${ }^{0000-0003-3285-3393}$ (V.P.) - Assoc. Prof., Faculty of Economics, Universitas Andalas, Indonesia, email: verapujani@eb.unand.ac.id.

Laura Syahrul ${ }^{0000-0002-7952-1559}$ (L.S.) - Assoc. Prof., Faculty of Economics, Universitas Andalas, Indonesia, e-mail: laurasyahrul@eb.unand.ac.id.

\section{AUTHOR CONTRIBUTIONS}

Conceptualization, Y.Y.; Methodology, Y.Y. and V.P.; Software, Y.Y. and V.P.; Validation, Y.Y. and L.S.; Formal analysis, Y.Y. and V.P.; Investigation, Y.Y., V.P. and L.S.; Resources, Y.Y., V.P. and L.S.; Original draft preparation, Y.Y.; Review and editing, Y.Y., V.P. and L.S.; Visualization, Y.Y.; Supervision, Y.Y.; Project administration, L.S.; Funding acquisition, Y.Y.

\section{CONFLICTS OF INTEREST}

The authors declare no conflict of interest. The funders had no role in the design of the study; in the collection, analyses, or interpretation of data; in the writing of the manuscript, or in the decision to publish the results.

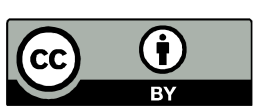

(C) 2021 by the authors. Submitted for possible open access publication under the terms and conditions of the Creative Commons Attribution (CC-BY) license (http://creativecommons.org/licenses/by/4.0/). 